\title{
Penile Cancer Pathologic Regional Lymph Nodes TNM Finding v8
}

National Cancer Institute

\section{Source}

National Cancer Institute. Penile Cancer Pathologic Regional Lymph Nodes TNM Finding v8. NCI Thesaurus. Code C140069.

A pathologic finding about one or more characteristics of penile cancer, following the rules of the TNM AJCC V8 classification system as they pertain to staging of regional lymph nodes. 